\title{
THE MALE MATING STRATEGY OF THE ANT FORMICA SUBPOLITA MAYR (HYMENOPTERA: FORMICIDAE): SWARMING, MATING, AND PREDATION RISK
}

\author{
By Kevin M. O’NeILL \\ Entomology Research Laboratory \\ Montana State University \\ Bozeman, MT 59717
}

\begin{abstract}
All-male mating swarms of the ant Formica subpolita were observed at the same site, and sometimes on the same plants, for six consecutive years (1988-1993) in southwestern Montana. The swarms, sometimes numbering thousands of males, occurred above and within shrubs and clumps of tall grasses. Mating occurred on the plant surface below the swarms and lasted for $62 \mathrm{~s}$ on average. Females controlled who they mated with and were observed to mate with up to 4 different males, before dispersing from swarm sites. I obtained $\sim 900$ records of predation on $F$. subpolita at swarms. Twenty-one species of predator were observed, the foremost of which were the robber fly Efferia staminea and the spider Dictyna coloradensis. With the exception of prey of the digger wasp Aphilanthops subfrigidus, which prey only on females, prey records were overwhelmingly male-biased. Results are compared to observations on other species of ants, especially those in the genus Pogonomyrmex.
\end{abstract}

\section{INTRODUCTION}

William Morton Wheeler (1910) characterized the male ant as "representing merely a fertilizing agency temporarily intruding itself on the activities of the community at the moment it becomes necessary to start other colonies". Despite Wheeler's lack of enthusiasm and his general assertion that male Hymenoptera are an "ethological non-entity" (Wheeler 1919), a number of studies of male ant behavior have appeared, some of which have been

Manuscript received 5 January 1994. 
detailed and quantitative (e.g. Hölldobler 1976, 1977, Davidson 1982, Elmes 1991, Bhatkar 1992). However, in a recent review of the mating strategies of ants, Hölldobler and Wilson (1990) noted a need for further comparative behavioral studies of nuptial flights and the behavior of both sexes during mating.

Hölldobler and Bartz (1985) classified the mating strategies of ants into two broad categories, the "female-calling syndrome" and the "male-aggregation syndrome". In the former, females attract males by releasing a sex pheromone at calling sites in the vicinity of their home nest. In the latter, males gather in swarms, to which females come to mate. Specific swarm sites may be used in consecutive years by different generations of males. Both scramble competition and interference competition among males may be intense, because of strong male-biased sex ratios at swarms (e.g. Hölldobler 1976). Female ants may mate just once, but multiple mating is apparently typical for many species (Hölldobler and Wilson 1990). Females can also potentially choose both the type and number of mates because of their ability to physically reject males (Hölldobler 1976).

Here, I report observations on the mating strategy of the ant Formica subpolita Mayr undertaken from 1988 through 1993 at sites in southwestern Montana. I describe male swarming behavior, persistence of swarm location within and between years, malefemale interactions, and extensive predation on males during swarms. Formica subpolita constructs nests in the form of mounds or craters in semi-desert areas of the western U.S. (Krombein et al. 1979), although it is also reported to nest beneath stones (Cole 1942). Apparently, little is known of its biology other than that it is frequently a slave of other species of Formica (Wheeler 1910, Wheeler and Wheeler 1963).

\section{MethodS}

I made observations at a site $14 \mathrm{~km}$ south of Three Forks, Gallatin County, Montana, U.S.A. $\left(45^{\circ} 45^{\prime} \mathrm{N}, 111^{\circ} 35^{\prime} \mathrm{W}\right)$ in June and July from 1988 through 1993 . I refer to this site as the Madison River site. I visited the site 44 times during the six-year period and focused observations around two clusters of skunkbrush sumac Rhus trilobata Nutt within a gulley $300 \mathrm{~m}$ west of the Madison River. 
I made focal behavioral observations of swarming males, mating pairs, and predations. I used sweep nets to sample the population of swarming ants and obtained prey records by retrieving ants from webs, or from feeding spiders and predaceous insects. Size of male ants is reported as head width and was measured using a microscope with an ocular micrometer.

\section{RESULTS}

\section{Swarming}

At the Madison site, males swarmed above shrubs (primarily $R$. trilobata) or small patches of cheatgrass (Bromus tectorum L.). Although these plants stood higher than most surrounding vegetation, they were not the highest points in the local environment, because both major swarm areas sat within a gully, the rim of which was higher than the tops of the plants.

Swarming males alternated flights with visits to plants above which the swarms occurred. Males flew in irregular patterns within the topmost part of the vegetation and up to $1 \mathrm{~m}$ above it and within $2 \mathrm{~m}$ of the ground. Flying males faced upwind, with their bodies generally oriented at an angle of $\sim 45^{\circ}$ to the ground (i.e. with venter down and head up). When wind direction changed within or between days, males changed their orientation to remain facing upwind. While in flight, they did not approach other airborne insects. Between brief flights, they landed on the stems and leaves of the vegetation and walked several $\mathrm{cm}$, often abruptly changing direction.

\section{Mating}

I observed as many as 51 matings at swarms in a single day. Prior to mating, females sat still on vegetation (i.e. Rhus stems or leaves, grass stems) at heights of 0.1 to $1.5 \mathrm{~m}$. Males either flew directly to perched females or walked to them after landing nearby on the plant. In a typical sequence, a male mounted a female dorsally, turned to orient in the same direction as her, and grasped her with his legs. If the female did not struggle (see below), the male probed with tip of his abdomen until genitalic contact was made. As soon as insertion occurred, the male released his leg grip and flipped backwards so that he was venter up.

After an interval typically less than $1 \mathrm{~min}$ in duration (mean \pm $\mathrm{SE}=27.1 \pm 2.4 \mathrm{~s}$, range: $4-63 \mathrm{~s}, \mathrm{~N}=36$ ), the female reached back 
and began to bite the male, usually in the region of the petiole, but also on the thorax, the gaster, or even the genitalic area. Such biting was observed in $88 \%$ of 41 matings observed from beginning to end. The pair often moved a short distance (i.e. less than $2 \mathrm{~cm}$ ) during this period. After the period of biting, the pair broke apart. It appeared that this was a result of the male pulling away from female, rather than being forced off. The mean length of the interval from the initiation of biting to termination of copulation was $35.0 \pm 3.0 \mathrm{~s}$ (range: $1-84 \mathrm{~s}, \mathrm{~N}=36$ ). The total duration of copulation, including 5 observations in which biting by the female was not observed was $62.0 \pm 2.4 \mathrm{~s}$ (range: $28-94 \mathrm{~s}, \mathrm{~N}=41$ ). I noted no obvious injuries occurring to males as a result of this biting.

When more than one male was with a female, the males not in copula mounted the female's thorax and probed with the abdomen in the same manner as a male alone with a female. However, it does not appear that direct attempts to remove the copulating male were made. Rather, each male (there may be up to five) simply attempts to mount and insert his genitalia. I found no evidence that larger body size enhanced a male's probability of mating. In samples from 1988, the mean head width of mating males (mean $=$ $1.638 \pm 0.015 \mathrm{~mm}, \mathrm{~N}=19$ ) was not significantly different from that of males collected from swarms with a sweep net (mean = $1.644 \pm 0.003, \mathrm{~N}=320 ; \mathrm{t}=0.39, \mathrm{P}>0.20$ ).

Homosexual mating attempts were common at certain times, especially late in the daily swarm period. The form of mounting and probing was similar to that for copulations. Males even mounted other males that were in spider webs or that were being carried by spiders.

Post-copulatory behavior

The male dispersed immediately upon pulling away from the female, usually dropping down into the vegetation. It is not known whether they returned to the swarm. It is possible that they did so, because, on several occasions, I observed a male to mate twice with the same female when individual pairs were confined in vials.

Some females remained in place and subsequently mated again (see below). Others either immediately left the swarm area, or did so after a short period in which they groomed their genitalia with their mouthparts. Some dispersed by dropping to the ground, walking out into the open, and then flying upwards to a height of 1-4 m 
before leaving the area. Alternatively, they flew out of the area directly from the their perches on the bushes. They had difficulty becoming airborne, particularly when taking off from perches close to the ground.

\section{Multiple mating}

Not all females left the swarm after mating. Some walked to another spot within the swarm or flew to a nearby shrub and mated again. I do not know the maximum number of times that females mated because their histories prior to my observations were unknown. However, I observed multiple matings by 8 unconstrained females on Rhus plants. Six of these females mated twice, one mated three times, and one four times, before rejecting further mating attempts. For the latter two females, all of the matings occurred over intervals of 10 and 22 minutes, respectively. Females rejected males by dropping off of their perches, walking away with their wings raised, or by moving the tip of their abdomens away from a male as he probed with his. I also made observations of 9 previously-mated females placed into insect nets with males. Six of these females mated with at least one more male, before rejecting further mating attempts by as many as seven different males.

\section{Spatial and temporal patterns of activity}

The duration of the daily swarm period varied, primarily because of variation in the time at which swarms ended. The mean time of arrival of the first swarming male, for 15 days on which this was noted, was $0922 \mathrm{~h}$ ( $\mathrm{SE}=3.9$, range: 0900-0957 h). The time of initiation did not appear to be strongly correlated with weather. It occurred as low as $14^{\circ} \mathrm{C}$ (ambient air temperature at swarm height) on a cool, partly cloudy day and as high as $24^{\circ} \mathrm{C}$ on a hot, clear day. The time of departure of the last swarming males was more difficult to determine, so it was recorded as occurring within 15 min intervals. The earliest departure time occurred during the 1015-1030 census on 3 July 1989, while the latest was recorded during the 1245-1300 census on 19 June, 1992.

I visited the Madison site on 31 days during the 1988-1993 field seasons, when swarming male alates of $F$. subpolita were present at one or both of the ant swarm areas. I classified fifteen of these days as high activity days, those in which at least one swarm was estimated to contain 50 or more males at its peak. On other days, as 
few as five males made up the largest swarms. The earliest date on which swarms occurred was 10 June 1992, while the latest date was 19 July 1989 . The greatest span of days over which swarms were observed was 34 in 1992. I did not observe swarms on 13 days that the site was visited between the first and last observed swarms of each year. However, there were undoubtedly a greater number of non-swarm days, because I did not visit the site on overcast or rainy days.

The gully in which the swarms occurred contained scattered shrubs (mostly $R$. trilobata) and small trees (mostly Juniperus sp.) throughout its length. However, swarms were commonly restricted to two clusters of $R$. trilobata separated by about $30 \mathrm{~m}$. I observed swarms in these two areas during all six seasons. In swarm area \#1, two of the Rhus had swarms present in all six seasons, and a third had swarms every year except 1993 . The greatest distance between Rhus on which swarms occurred was $8 \mathrm{~m}$. Swarms occurred on other Rhus in this area only on days when very large swarms were present, in 1988, 1989, and 1992.

Swarm area \#2 was about $30 \mathrm{~m}$ east of swarm area \#1, in a semicircular expansion of the gully, where the Rhus formed a crescent-shaped array $20 \mathrm{~m}$ across. Here, the position of the major swarms (i.e. those occupied on all days that swarms were present) varied more between years. In 1988, the major swarms occurred on two Rhus on the $\mathrm{N}$ edge of the crescent and two on the NE edge. Smaller swarms occurred on three of these Rhus in 1989, but never again during the study. In 1989, the focus of activity shifted to a small Rhus near the W side of the crescent. From 1990-1993, the major swarms occurred on Rhus and patches of Bromus in the NW edge of the crescent. There were no obvious differences in the size, location, or foliage of Rhus with and without swarms. During the course of the study, I did not locate any nests from which swarming male $F$. subpolita were emerging.

I did not directly measure male density in swarms, but peak densities of at least 100 males above an area of $1 \mathrm{~m}^{2}$ were observed. However, on other days, fewer than 10 males were present on a shrub, so that densities were as low a $1-2 \mathrm{males} / \mathrm{m}^{2}$. The area covered by discrete swarms was relatively small, typically being the 1-4 $\mathrm{m}^{2}$ area of the crown of a shrub or the clump of cheatgrass. However, occasionally the swarms grew in extent dur- 
ing the morning until the swarms on bushes separated by 1 or $2 \mathrm{~m}$ became contiguous. For example, on 1 July, 1988, I observed the first males in swarm area \#2 at 0913 and by 0930 swarms at several Rhus contained 50-100 males. By 1030, the swarms had expanded so that most of the vegetation, including low lying grasses and forbs between the shrubs were within the area of a single giant swarm. I estimated that the area of this "swarm" to be at least $2,500 \mathrm{~m}^{2}$, although the density of males was not homogeneous.

The sex ratio at swarms was probably strongly male-biased, both because of the fewer numbers of females present at swarms at any time and because of the shorter residence times of females. Even when hundreds of males swarmed on a Rhus, I never saw more than 10 females present at any point in time.

Predation on swarming alates

I observed twenty-one species preying upon alates during swarms. The most common predators were robber flies (Diptera: Asilidae) and spiders (Arachnidae: Araneae). The five species of robber flies were Efferia staminea, Stenopogon inquinatus, Megaphorus willistoni, Machimus occidentalis, and Machimus

Table 1. Sex ratio of Formica subpolita in prey taken during swarms.

\begin{tabular}{|c|c|c|c|c|c|}
\hline \multirow[b]{2}{*}{ Predator } & \multirow[b]{2}{*}{ Year } & \multicolumn{2}{|c|}{ Sex of Prey } & \multirow[b]{2}{*}{$\%$ Males } & \multirow{2}{*}{$\begin{array}{l}\text { Chi-square } \\
\text { Probability }^{3}\end{array}$} \\
\hline & & Females & Males & & \\
\hline \multirow[t]{4}{*}{ Arachnida $^{1}$} & 1988 & 0 & 78 & 100 & $\mathrm{P}<0.0001$ \\
\hline & 1991 & 0 & 64 & 100 & $\mathrm{P}<0.0001$ \\
\hline & 1992 & 0 & 115 & 100 & $P<0.0001$ \\
\hline & Total & 0 & 257 & 100 & $\mathrm{P}<0.0001$ \\
\hline \multicolumn{6}{|l|}{ Hemiptera } \\
\hline Z. tetracanthus & 1992 & 0 & 5 & 100 & $P=0.03$ \\
\hline \multicolumn{6}{|l|}{ Asilidae } \\
\hline \multirow[t]{2}{*}{ E. staminea } & 1988 & 2 & 91 & 93 & $\mathrm{P}<0.0001$ \\
\hline & 1989 & 1 & 450 & 99 & $\mathrm{P}<0.0001$ \\
\hline M. occidentalis & 1992 & 1 & 18 & 95 & $\mathrm{P}<0.0001$ \\
\hline S. inquinatus & $1987-1990$ & 0 & 65 & 100 & $\mathrm{P}<0.0001$ \\
\hline All Asilidae & Total & 4 & 624 & 99 & $P<0.0001$ \\
\hline \multicolumn{6}{|l|}{ Sphecidae } \\
\hline A. subfrigidus ${ }^{2}$ & $1987-1992$ & 23 & 0 & 0 & $P<0.0001$ \\
\hline
\end{tabular}


formosus. All but the last species flew into swarms to take prey. Machimus formosus preyed only upon the alates when the ants flew within range of their perches at the entrance of mammal burrows (O'Neill \& Kemp 1992). The vast majority of the prey of the robber flies were males (Table 1). I obtained some of the prey records as part of research on the robber flies of the area (O'Neill 1992, O'Neill and Kemp 1991). Males taken as prey by robber flies in 1988 were not significantly different in size (mean $=1.635 \pm$ $0.010, \mathrm{~N}=63$ ) from males in the sample from swarms (mean = $1.644 \pm 0.003, \mathrm{~N}=320 ; \mathrm{t}=1.29, \mathrm{P}>0.20$ ).

Seven species of spiders preyed on the ants: Dictyna coloradensis (Dictynidae), Metepeira foxi (Araneidae), Tetragnatha laboriosa (Araneidae), Philodromus sp. (Philodromidae), Tibellus duttoni (Philodromidae), Habronattus sp. (Salticidae), and Misumenops celer (Thomisidae). All of the prey were males (Table 1). The diffuse webs of $D$. coloradensis, which often contained more than a single spider, were common on the tips of branches of the Rhus on which the swarms occurred. The vast majority of the male ants among spider prey that I collected were retrieved from the webs of D. coloradensis. For example, on 25 June 1992, a day on which intermediate-sized swarms were present, I collected 44 prey from webs, 41 from $D$. coloradensis, 2 from $T$. laboriosa, and 1 from M. foxi. In contrast to the data for robber flies, body size of $F$. subpolita apparently influences susceptibility to predation by spiders. Males collected from spider webs in 1988 were slightly, but significantly larger on average $($ mean $=1.659 \pm 0.007, \mathrm{~N}=78$ ) than males from swarms (mean $=1.644 \pm 0.003, \mathrm{~N}=320 ; \mathrm{t}=2.02$, $\mathrm{P}<0.05)$.

The only common insect that took females rather than males was the sphecid wasp Aphilanthops subfrigidus. Female $F$. subpolita were the only prey found in nests of this species located 5 to $20 \mathrm{~m}$ away from the swarms (O'Neill 1990). They were frequently observed flying among the branches of the sumac on which the female ants perched. On four occasions, I observed female wasps capturing, stinging, and carrying off females. On a fifth occasion, a female attempted to capture a female that was in copula, but succeeded only in breaking up the mating pair, which dispersed. The swarms were also the focus of activities of the male A. subfrigidus that maintained mating territories on the sumac. These territories 
were only rarely observed away from the swarms (O'Neill 1990) and their seasonal occurrence coincided closely with the seasonal activity of the alate ants. From 1990 to 1992 , territories were present in the swarm areas on 14 of 16 days on which swarms occurred, and never when swarms were absent.

Other insect predators of the males at the swarms included two species in the family Reduviidae, Zelus tetracanthus ( $\mathrm{N}=5$ predations) and Sinema diadema ( $\mathrm{N}=1$ nymph), and one species in the family Nabidae Nabicula vanduzei $(\mathrm{N}=1)$. I also observed an unidentified species of dragonfly (Odonata: Anisoptera) feeding at swarms on several days and frequently saw workers of Formica sp. dragging struggling males away from swarms.

The birds observed feeding on the ants were very irregular visitors to the swarms. On a single day in 1989 , six cedar waxwings (Aves: Bombycillidae, Bombycilla cedrorum) perched amid a swarm and fed upon flying alates. One individual fed on at least 50 ants, apparently having little difficulty in capturing them. On several days, cliff swallows (Hirundinidae, Petrochelidon pyrrhonota) and violet-green swallows (Hirundinidae, Tachyneta thalassina) apparently also fed on the ants while flying through the swarms.

Swarms of other species

Swarms sometimes contained more than one species of ant. Mating pairs of three other Formica sp. were found at the same Rhus plants on which males of $F$. subpolita were swarming on 8 days. Males and females of all three of the species were distinctly different in size and color than individuals of $F$. subpolita. On several days when swarms were small (i.e. less than $\sim 50$ males), males of one of the species were often as common as those of $F$. subpolita and their swarming behavior was similar, but the form and duration of mating behavior were different (unpublished observations).

On two days in 1988, swarms sometimes numbering thousands of males of a Leptothorax sp. also formed on Rhus at the Madison site. On one of these days, $F$. subpolita swarms occurred on the same shrubs. However, the Leptothorax swarms tended to be compact and occupy only the highest branches of the shrubs. In fact, the swarms of this species would immediately migrate to surround the head of an observer if the latter was within $1 \mathrm{~m}$ of the swarms and higher than the highest point on the Rhus. If the observer then crouched, the swarm migrated back to the bush. Several mating pairs were 
observed, but detailed observations of the behavior of this species were not made. Efferia staminea (O'Neill 1992) and Dictyna coloradensis also preyed upon Leptothorax males during swarms.

\section{Discussion}

Observations of males of the genus Formica indicate that some species have strategies referred by Hölldobler and Bartz (1985) as the "female-calling syndrome" (e.g. Kannowski and Johnson 1969, Halverson et al. 1976, Henderson and Jeanne 1992), while others display the "male aggregation syndrome" (Talbot 1972). The mating strategy Formica subpolita clearly falls within the latter category. The specific location of the swarm sites of this species was consistent within and between seasons, for as long a six years in some locations, even though the males in each year undoubtedly represented different generations. Repeated use of swarm sites over 2 to 3 year intervals has been observed in 4 species of ants in the genus Pogonomyrmex (Hölldobler 1976), in Acromyrmex versicolor (Johnson and Rissing 1993), and in Formica obscuripes (Talbot 1972). "Traditional" non resource-based male aggregation sites have also been observed in other insects, such as the pompilid wasp Hemipepsis ustulata (Alcock 1981), the digger wasps Philanthus basilaris (O'Neill 1983), P. crabroniformis, and P. barbatus (Evans 1993), and the bombyliid Compostia sp. (Yeates and Dodson 1990).

In many species of ants, swarms typically form on or around conspicuous high points in the overall landscape, such as hilltops or man-made structures (Chapman 1963, Nagel and Rettenmeyer 1973, Hölldobler 1976, Leprince and Francoeur 1986). In others, swarms occur either at ground level (Talbot 1971, Hölldobler 1976) or on short plants (Talbot 1972, Rust 1988). The swarms of F. subpolita occurred on shrubs within a gully which had a rim higher than the shrubs and which was adjacent to a hill at least 40 $\mathrm{m}$ higher than the gully floor. Furthermore, the shrubs occupied by the swarms were not always the tallest plants in the local environment. Thus, I cannot speculate on what visual cues the ants use to identify swarm sites, although different species in the mixed swarms apparently used the same cues. Once swarms form, pheromones used by the ants could serve to attract conspecifics (Hölldobler and Wilson 1990), but I have no evidence that these are used by $F$. subpolita. 
Males of other species of Formica also swarmed on the same shrubs as $F$. subpolita and males of the different species intermingled in the swarms. Mixed ant swarms have been observed by others (Chapman 1963, Leprince and Francoeur 1986). The swarms of F. subpolita at our site were slightly segregated in space from those of Leptothorax sp., the latter focusing their activity around the highest protruding branches on the shrubs. Leprince and Francoeur (1986) observed such segregation over short distances at a hilltop where L. longispinosus Roger and Myrmica sp. swarmed.

My observations suggest that scramble, rather than interference, competition is used by $F$. subpolita males at the swarm sites. Individual males rapidly fly over the vegetation, frequently landing to search the surface of small areas of the plant. When a mating pair was discovered by other males, the new males attempted to mount and couple, but I observed no obvious attempts to physically disrupt the mating pair and saw no matings interrupted by the presence of additional males. Probably because of the lack of interference competition, I found no evidence that larger males had an advantage in competition for females. My observations contrast with those of Hölldobler (1976) who observed male Pogonomyrmex pulling copulating males away from females. The maximum number of males present during copulation in F. subpolita (i.e. 6) was also lower than observed in species of Pogonomyrmex, where as many as 11 (Hölldobler 1976), 20 (Nagel and Rettenmeyer 1973), or more (Lavigne and Fisser 1966) males may be present.

As observed in other species of ants (Hölldobler 1976, Davidson 1982, Mintzer 1982), F. subpolita were able to reject mating attempts by physically repelling males or by dispersing. There is evidence, from ants of other genera, that females may discriminate among potential mates by species (Hölldobler 1976), body size (Davidson 1982), and nest of origin (Bhatkar 1992). By being able to reject mates, females controlled the number of times they mated. The maximum number of matings that I observed for an individual female (i.e. four), is the same as the maximum previously observed for a species of Formica (Kannowski 1963, Hölldobler and Wilson 1990). It is not known whether each male mating with a female passes the same amount of sperm or whether the female's spermatheca fills before the final male mates. Unlike 
Pogonomyrmex (Hölldobler 1976), females of $F$. subpolita do not mate in rapid sequence with different males, but with delays of several minutes between copulations. Although males seem to pull away from females at the end of copulation, the females may also have some control over the duration of mating. In most cases, they apparently used biting of the male to force him off or to signal that copulation was about to end. The use of biting by females to control the duration of mating has also been observed in Pheidole sitarches Wheeler (Wilson 1957), Pogonomyrmex spp. (Nagel and Rettenmeyer 1973, Hölldobler 1976, Rust 1988), and Monomorium mininum (Bhatkar 1992). In other species, the females apparently remain passive throughout copulation (e.g. Villet et al. 1989).

The conspicuous mating activities of male insects commonly increase their risk of predation to predators (Thornhill and Alcock 1984). Male $F$. subpolita were susceptible to spider predation because they swarmed at shrubs with high numbers of spider webs and because, as relatively small, weak flying insects, they had difficulty escaping from webs once contact was made. Males also seem especially vulnerable to capture by large, strong flying predators such as robber flies (O'Neill 1992). Because many robber flies prey on flying insects, they are attracted to the activities of male insects that swarm (O'Neill and Bjostad 1987) or pursue potential mates (Gwynne and O'Neill 1980). The robber flies Efferia staminea and Stenopogon inquinatus in the F. subpolita swarm areas changed to almost exclusive use of $F$. subpolita as prey on many of the swarm days (O'Neill 1992, O'Neill and Kemp 1992). For $E$. staminea, the higher availability of male ants during swarm periods was also correlated with dramatically higher foraging success and lower rates of cannibalism (O'Neill 1992). Reports of diet composition and predator behavior often include records of large numbers of alate ants taken by predators such as swallows (Bent 1942), vespid wasps (Chapman 1963), empidid flies (Evans 1988), and robber flies (Dennis and Lavigne 1975, Lavigne and Holland 1969).

The relative risk of predation experienced by the two sexes at swarms cannot be assessed, because I made no determination of the overall sex ratio at swarms; this would have been difficult, because visual counts would have been impossible and because sweep samples of the aerial swarms would have missed the females perching 
on the shrubs below. However, observations of both ants and predators suggest that females may be less vulnerable to predation than males at swarms. Female $F$. subpolita remained stationary in lower portions of the plants for most of the time they were present. Because of this, they were less likely to be taken by the robber flies, which ambush flying prey, and by the spider Dictyna coloradensis, whose abundant webs were primarily on the tips of branches. Although rare in the prey records at swarms, the potentially longer-lived female $F$. subpolita may suffer high predation rates elsewhere, while searching for nest sites and excavating nests, and even during the early phases of the colony life cycle. Whitcomb et al. (1973) provide an extensive catalog of predators of alate and founding queens of Solenopsis invicta Buren, that includes records of birds, dragonflies, ants, and other invertebrates as predators. Other records of such predations on female reproductives also appear in the literature (citations in Whitcomb et al. 1973).

\section{ACKNOWLEDGMENTS}

I thank James Cokendolpher for identifying the spiders, Eric Fisher and C. Riley Nelson for identifying the robber flies, Andre Francoeur for identifying the ants, and Richard Miller for identifying the Reduviidae. Ruth O'Neill, Erin O'Brien, and James Cummins provided assistance with the research. Howard Evans, Jeffrey Littlefield, Wendell Morrill, Peter Nonacs, and Xinzhi Ni provided useful comments on the manuscript. The research was supported by U.S.D.A. Agricultural Research Service, U.S.D.A. APHIS, Plant Protection and Quarantine, and the Montana Agricultural Experiment Station. Contribution number J-2912, Montana Agricultural Experiment Station.

\section{REFERENCES}

Alcock, J. 1981. Lek territoriality in the tarantula hawk wasp Hemipepsis ustulata (Hymenoptera: Pompilidae). Behav. Ecol. Sociobiol. 8: 309-317.

Bent, A.C. 1942. Life Histories of North American Flycatchers, Larks, Swallows, and Their Allies. Washington, D.C.: Smithsonian Institution, U.S. National Museum.

Bhatkar, A.P. 1992. Mating success in Monomorium minimum (Hymenoptera: Formicidae). J. Kans. Entomol. Soc. 65: 244-250. 
Chapman, J.A. 1963. Predation by Vespula wasps on hilltop swarms of winged ants. Ecology 44: 766-767.

Cole, A.C. 1942. The ants of Utah. Amer. Midl. Nat. 28: 358-388.

Davidson, D.W. 1982. Sexual selection in harvester ants (Hymenoptera: Formicidae: Pogonomyrmex). Behav. Ecol. Sociobiol. 10: 245-250.

Dennis, D.S., and Lavigne, R.J. 1975. Comparative behavior of Wyoming robber flies II (Diptera: Asilidae). Univ. Wyoming Agric. Exp. Sta. Sci. Mono. 30: $1-68$.

Elmes, G.W. 1991. Mating strategy and isolation between the two forms, macrogyna and microgyna, of Myrmica ruginodis (Hym. Formicidae). Ecol. Entomol. 16: 411-423.

Evans, H.E. 1988. Observations on swarms of Rhamphomyia sociabilis (Williston)(Diptera: Empididae). J. N.Y. Entomol. Soc. 96: 316-322.

. 1993. Observations on aggregations of males of two species of beewolves (Hymenoptera: Sphecidae, Philanthus). Psyche 100: 25-33.

Gwynne, D.T., and O'Neill, K.M. 1980. Territoriality in digger wasps results in sex-biased predation on males (Hymenoptera: Sphecidae, Philanthus). J. Kans. Entomol. Soc. 53: 220-224.

Halverson, D.D.; Wheeler, J.; and Wheeler, G.C. 1976. Natural history of the sandhill ant, Formica bradleyi (Hymenoptera: Formicidae). J. Kans. Entomol. Soc. 49: $280-303$.

Henderson, G., and Jeanne, R.L. 1992. Population biology and foraging ecology of prairie ants in southern Wisconsin (Hymenoptera: Formicidae). J. Kans. Entomol. Soc. 65: 16-29.

Hölldobler, B. 1976. The behavioral ecology of mating in harvester ants (Hymenoptera: Formicidae: Pogonomyrmex). Behav. Ecol. Sociobiol. 1: 405-423.

- 1977. Mating behavior and sound production in harvester ants (Pogonomyrmex, Formicidae). Insectes Sociaux 24: 191-212.

Hölldobler, B., and Bartz, S.H. 1985. The sociobiology of reproduction in ants. pp. 237-257 In B. Hölldobler and M. Lindauer, eds, Experimental behavioral ecology and sociobiology. Sinauer Associates: Sunderland, Mass.

Hölldobler, B,. and Wilson, E.O. 1990. The Ants. Cambridge, Mass: Harvard University Press.

Johnson, R.A., and Rissing, S.W. 1993. Breeding biology of the desert leafcutter ant Acromyrmex versicolor (Pergande) (Hymenoptera: Formicidae). J. Kans. Entomol. Soc. 66: 127-128.

Kannowski, P.B. 1963. The flight activities of formicine ants. Symp. Genet. Biol. Ital. 12: 74-102.

Kannowski, P.B., and Johnson, R.L. 1969. Male patrolling behavior and sex attraction in ants of the genus Formica. Anim. Behav. 17: 425-429.

Krombein, K.V.; Hurd, P.D.; Smith, D.R.; and Burks, B.D. 1979. Catalog of Hymenoptera of America North of Mexico. Smithsonian Institution Press: Washington, D.C.

Lavigne, R.J., and Fisser, H.G. 1966. Controlling western harvester ants. U.S. Dept. Agr. Mountain States Reg. Publ. 3.

Lavigne, R.J., and Holland, F.R. 1969. Comparative behavior of eleven species of Wyoming robber flies (Diptera: Asilidae). Univ. Wyoming Agric. Exp. Sta. Sci. Mono. 18: 1-61. 
Leprince, D.J., and Francoeur, A. 1986. Hilltop swarming by ants (Hymenoptera: Formicidae) in southwestern Quebec and interspecific competition at the swarm marker. Ann. Entomol. Soc. Amer. 79: 865-869.

Mintzer, A.C. 1982. Copulatory behavior and mate selection in the harvester ant, Pogonomyrmex californicus (Hymenoptera: Formicidae). Ann. Entomol. Soc. Amer. 75: 323-326.

Nagel, H.G., and Rettenmeyer, C.W. 1973. Nuptial flights, reproductive behavior, and colony founding in the western harvester ant Pogonomyrmex occidentalis (Hymenoptera: Formicidae). J. Kans. Entomol. Soc. 46: 82-101.

O'Neill, K.M. 1983. Territoriality, body size, and spacing in males of the beewolf Philanthus basilaris (Hymenoptera; Sphecidae). Behaviour 86: 295-325.

. 1990. Female nesting behavior and male territoriality in Aphilanthops subfrigidus Dunning (Hymenoptera: Sphecidae). Pan-Pac. Entomol. 66: 19-23.

- 1992. Temporal and spatial dynamics of predation in a robber fly population (Diptera: Asilidae, Efferia staminea). Canadian Journal of Zoology 70: 1546-1552.

O'Neill, K.M., and Bjostad, L. 1987. The male mating strategy in the bee Nomia nevadensis (Hymenoptera: Halictidae): leg structure and mate guarding. PanPac. Entomol. 63: 207-217.

O'Neill, K.M., and Kemp, W.P. 1991. Foraging of Stenopogon inquinatus Loew on Montana rangeland sites. Pan-Pac. Entomol. 67: 177-180.

1992. Behavioral thermoregulation in two species of robber flies (Diptera: Asilidae, Machimus) occupying different grassland microhabitats. Journal of Thermal Biology 17: 323-331.

Rust, R.W. 1988. Nuptial flights and mating behavior in the harvester ant, Pogonomyrmex salinus Olsen (Hymenoptera: Formicidae). J. Kans. Entomol. Soc. 61: 492-494.

Talbot, M. 1959. Flight activities of two species of ants of the genus Formica. Amer. Midl. Nat. 61: 124-132.

1971. Flights of the ant Formica dakotensis Emery. Psyche 84: 169-179.

1972. Flights and swarms of the ant Formica obscuripes Forel. J. Kans. Entomol. Soc. 45: 254-258.

Thornhill, R., and Alcock, J. 1983. The Evolution of Insect Mating Systems. Harvard University Press: Cambridge, MA.

Villet, M.; Crewe, R.; and Robertson, H. 1989. Mating behavior and dispersal in Paltothyreus tarsatus Fabr. (Hymenoptera: Formicidae). J. Ins. Behav. 2: 413-417.

Wheeler, W.M. 1910. Ants: Their Structure, Development, and Behavior. Columbia University Press: New York.

- 1919. The parasitic aculeata: a study in evolution. Proc. Amer. Philos. Soc. 58: $1-40$.

Wheeler, G.C., and Wheeler, J. 1963. The ants of North Dakota. University of North Dakota Press: Grand Forks.

Whitcomb, W.H.; Bhatkar, A.; and Nickerson, J.C. 1973. Predators of Solenopsis invicta queens prior to successful colony establishment. Environ. Entomol. 2: 1101-1103.

Wilson, E.O. 1957. The organization of the nuptial flight of the ant Pheidole sitarches Wheeler. Psyche 64: 46-50. 
Yeates, D., and Dodson, G. 1990. The mating system of a bee fly (Diptera: Bombyliidae). I. Non-resource-based hilltop territoriality and a resource-based alternative. J. Ins. Behav. 3: 603-617. 

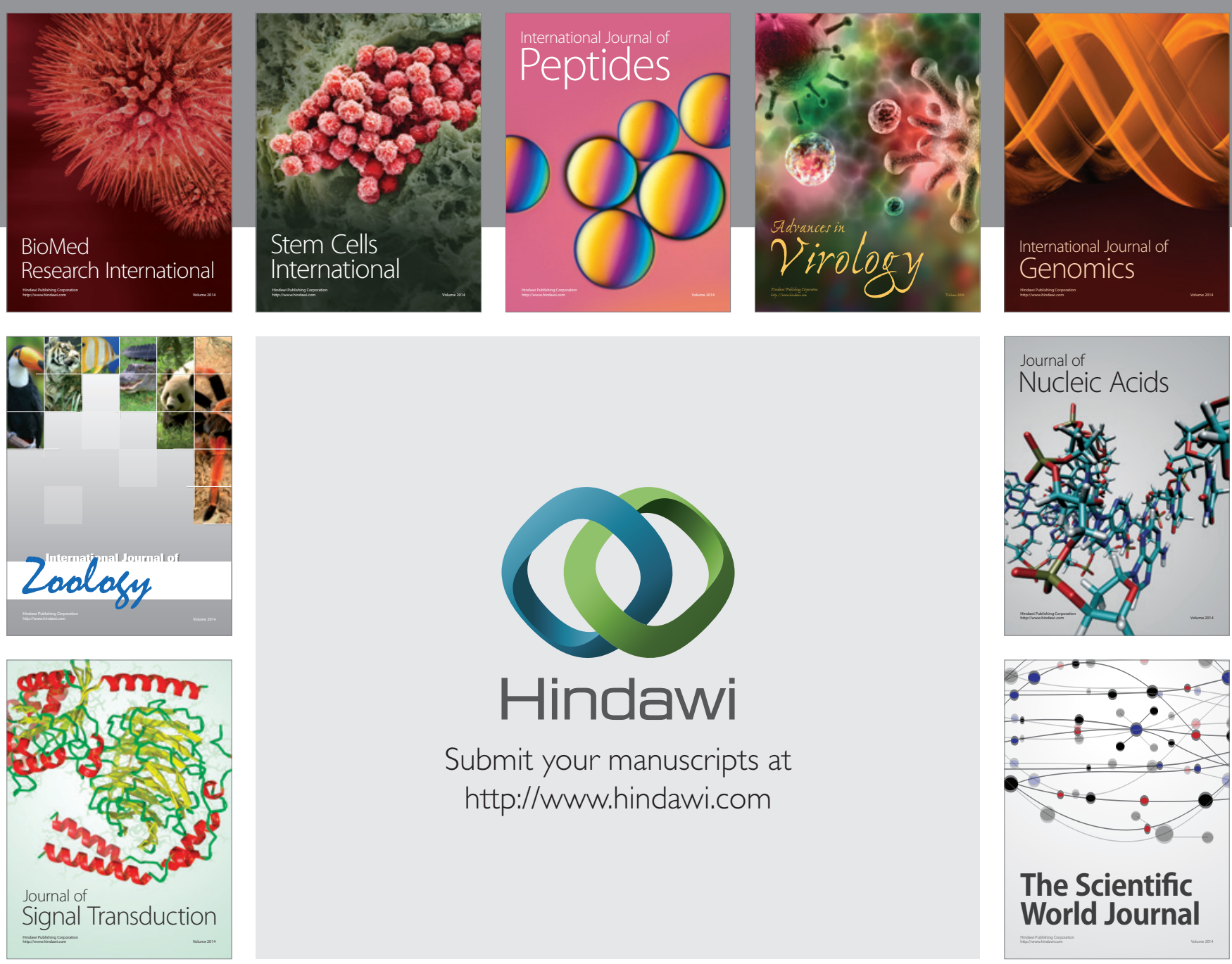

Submit your manuscripts at

http://www.hindawi.com
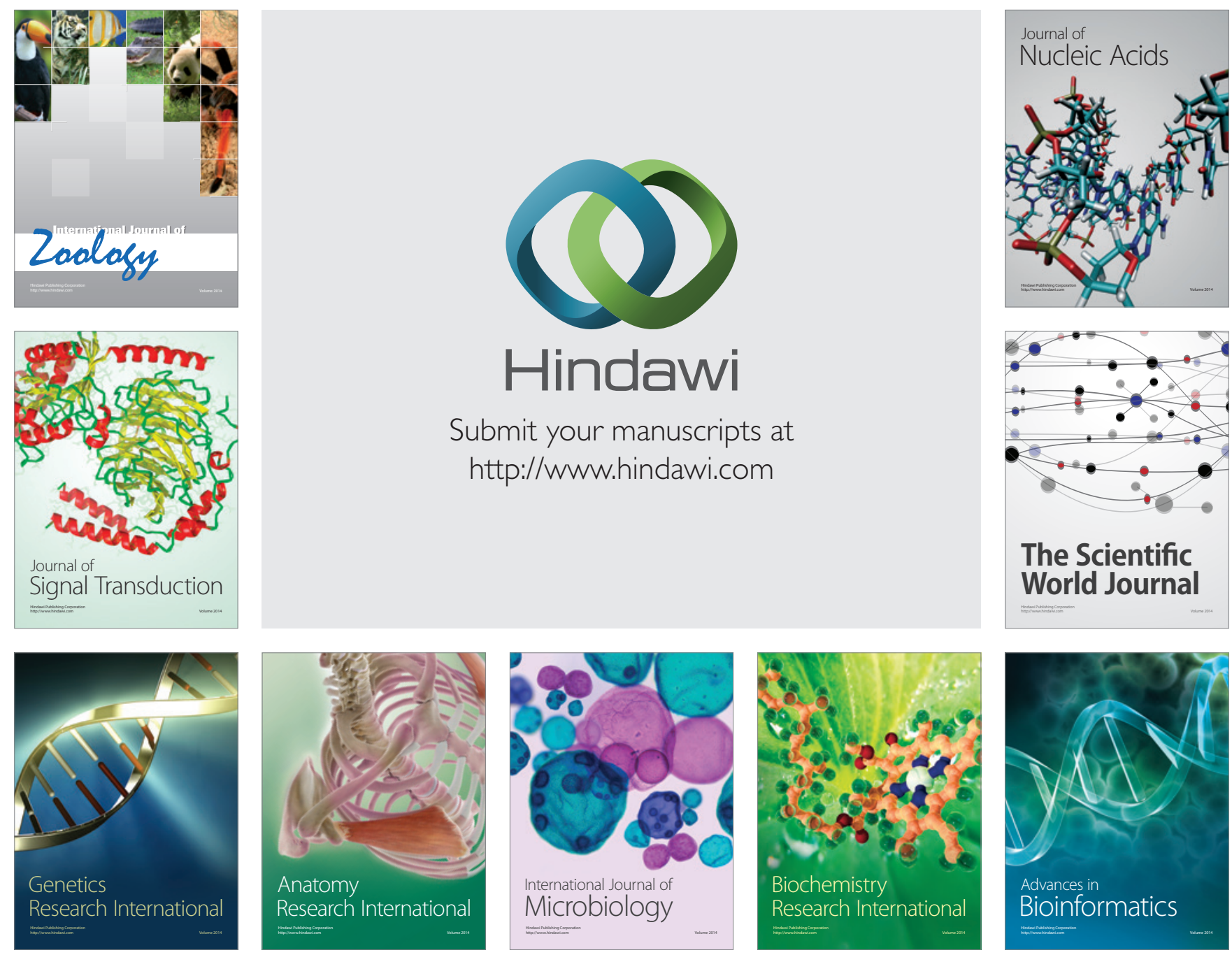

The Scientific World Journal
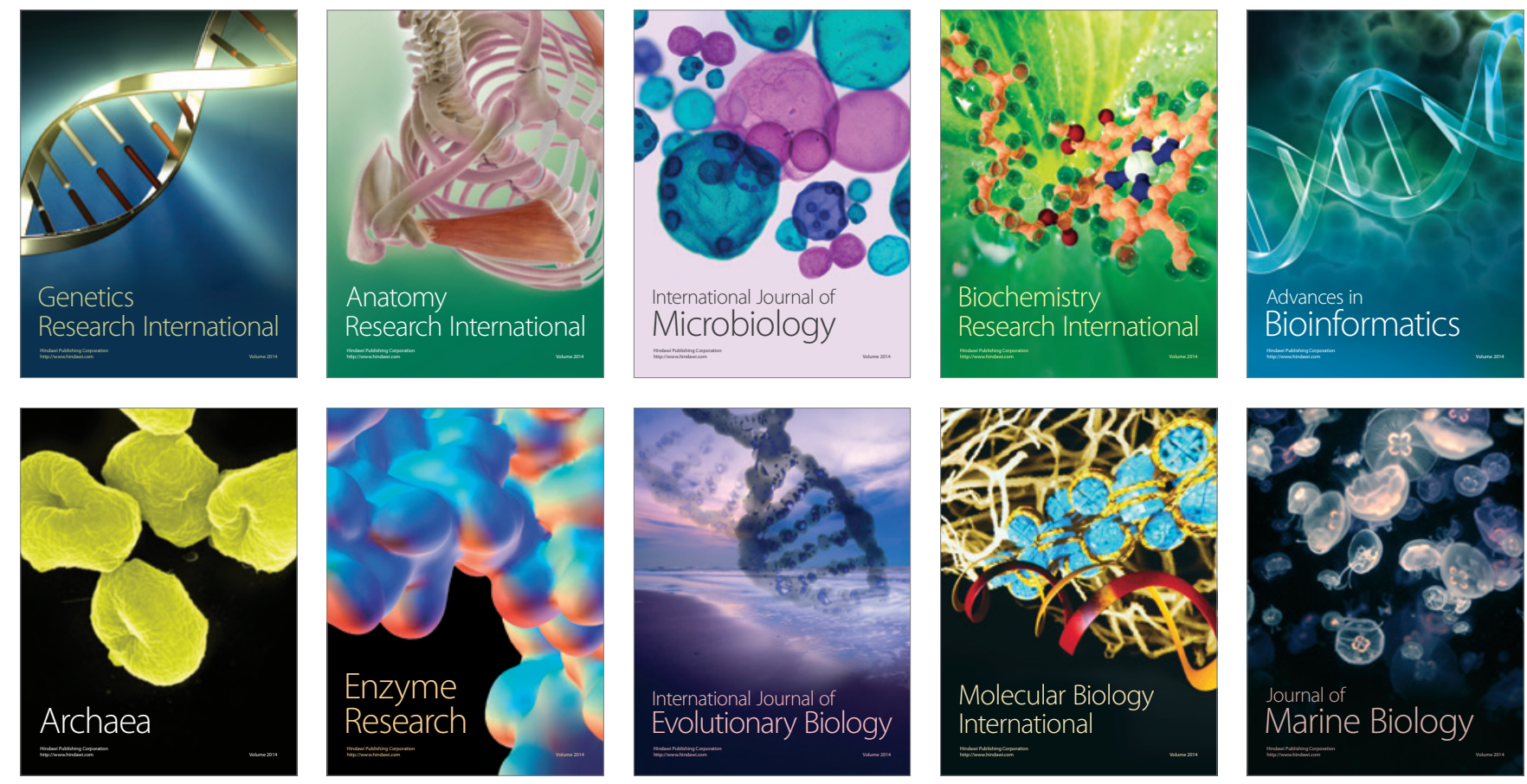